\title{
The Development of Organic Tourism Villages Based on Participation and Local Wisdom in Indonesia
}

\author{
Agung Wibowo ${ }^{*}$, Ravik Karsidi $^{2}$, Bani Sudardi $^{3}$ and Mahendra Wijaya ${ }^{4}$ \\ ${ }^{1}$ Faculty of Agriculture, Universitas Sebelas Maret J1. Ir. Sutami 36 A, Surakarta, Indonesia \\ ${ }^{2}$ Doctoral Program in Development Exstension, Graduate School, Universitas Sebelas Maret, Jl. Ir. \\ Sutami 36 A, Surakarta, Indonesia \\ ${ }^{3}$ Department of Sociology, Universitas Sebelas Maret, Jl. Ir. Sutami 36 A, Surakarta, Indonesia \\ ${ }^{4}$ Faculty of Cultural Studies, Universitas Sebelas Maret, Jl. Ir. Sutami 36 A, Surakarta, Indonesia
}

\begin{abstract}
Participation and local wisdom are the basis for building the success of a tourist village. In a participative based tourist village, work opportunities can be created for the local community to help reduce poverty. The development model for a tourist village based on local wisdom provides the opportunity for the community to show the identity of its ecotourism and display its own uniqueness. The goal of the research is to understand the potential of social behavior that occurs in activities between individuals in the community, including aspects of participation and local wisdom in the success of developing organic tourist village. A qualitative research method is used which focuses on an investigation of the way human beings interpret values of local wisdom and the significance of participation in the development of the organic tourist village. In the research of a case study, to collect data which involve various sources of information (observation, interview, focus group discussion, audio-visual material, document, and report). The research results show that the development organic tourist village of Blederan based on participation and local wisdom. It impact to sustainability and independence of the community in resource management.
\end{abstract}

\section{Introduction}

Changes in the cultural regime of post modernization gave rise to new forms of tourism, such as pro-poor tourism, community based tourism, and community benefit tourism initiatives. Local communities act as the subject, where cultural elements play an important role [1]. Their participation is a motivating factor that can preserve the unique value of tourism [2], and is one of the most influential factors in the environment [3]. Therefore, in developing a local wisdom based tourist village, the local community, stakeholders, and local operators need to be given the necessary attention to maps the traditions of a

\footnotetext{
* Corresponding author: agungwibowo@staff.uns.ac.id
} 
community as its local wisdom, customs, music and dance, traditional clothes, and special foods $[4,5]$.

In a participative based tourist village, work opportunities can be created for the local community, which help to reduce poverty, where the income from ecotourism is procured from tourism services such as transportation, tourist guides, accommodation, and the sale of local handicrafts. The success of introducing sustainable development lies in the support and participation of those involved in the tourism business [6]. The involvement of the government together with local communities is vital to ensure that the development meets the needs of the community concerned, based on the assumption that the community has more knowledge about the potential of its own area. This is in line with the opinion of [7], namely that a community approach is the standard approach used in the development of a tourist village.

In a community approach, the model formulated must represent community participation in every aspect, and must of course guarantee that the tourist village program is in accordance with the needs of the community, as well as ensuring that the community is committed to developing the tourist village by offering attractions that encourage tourists to visit, with the proper facilities, accessibility and promotion that will increase the number of tourists visiting the tourist village [2]. Community empowerment in this context can be defined as: "an endeavor to strengthen and increase the capacity, role, and initiative of the community as one of the stakeholders, to be able to participate and play an active role as the subject or actor, and as the beneficiary in the development of a sustainable tourist village" [8],. Tourism awareness is described as a form of awareness of the community to properly embody its role and responsibility as a good host for guests or tourists, in order to create a conducive environment. The principles of good practice formulated in community empowerment aim to encourage active participation and representation, enabling all members of the community to significantly influence the decisions that affect their own lives [9].

The implementation of an attitude of tourism awareness will develop a proportional understanding between the various parties involved, which in turn will encourage the community to participate in the tourism endeavor [10]. Ultimately, ecotourism will have a positive impact on environmental conservation, local wisdom, and cultural preservation in the local community. The preservation of local culture and local wisdom will also indirectly cultivate the identity and sense of pride of the local citizens. This will happen alongside an increase in ecotourism activities [11]. The lives of rural communities in various parts of Indonesia are still strongly bound to the high noble values of their culture. Local wisdom can be defined as a local cultural wealth that contains life policies and life views which accommodate knowledge and wisdom about life [12].

The development model for a local wisdom based tourist village allows the opportunity for the community to show the identity of its ecotourism and display its own unique character that can be used to distinguish it from the ecotourism in other places [13]. Local wisdom based tourism, is an activity in which the local people are involved in providing and controlling their culture as an essence of the attraction. That is designed using an approach based on local wisdom becomes an alternative tourist attraction [14]; [5]; [12]; [15]. Local wisdom has been proven to have the ability to preserve the balance in the life of a harmonious community, and to be durable and sustainable. As a concept with various forms of spatial implementation, the local wisdom of a community will continue to grow within the awareness of the community [16]. As an example is the tourist village of Penglipuran, which are the harmonious relations between man and God, man and man, and man and the environment. The process of community empowerment through the development of the Penglipuran tourist village consisted of three stages, including the stage of creating awareness, the stage of maximizing capacity, and the stage of empowering[17]. 
The function of the development of a tourist village is to provide a direct space for the community to cultivate an awareness of the existence of potential tourism opportunities. The development of a tourist village can also serve as a tool for revitalizing cultures, traditions, or the traditional environment as a tourist commodity, and ensuring the continued existence of these cultures and traditions [18]. The collective effort to strengthen the relationship between tourism and protected farmland, to expand the reach of tourism products, and to bolster the image of nature, the countryside, and the attraction of the area [19]. The tourism industry has a strong potential for revitalizing village communities, amongst others by increasing economic growth and providing work opportunities [20]. Local communities and experts have long since believed in the idea of utilizing tourism as a way to reduce poverty. Village tourism is an industry that efficiently integrates nature and agriculture with local communities and modern tourism, and as a result of the rapid increase in urbanization, rural areas are becoming the choice for the urban population [21].

Based on these studies, it has been shown that strong community participation contributes to the effectiveness of the development process while local wisdom guides the community in building community sustainability and independence. The synergy between participation and local wisdom is a social capital that plays a very important role in the development of a tourist village. Village tourism activities in developed countries have played an important role in advancing villages. The current research aims to describe how participation and local wisdom are important factors in the success of building organic tourist village.

\section{Research Methods}

This research focuses on a community at Blederan Village, Mojotengah District, Wonosobo Regency. That is the target of Corporate Social Responsibility (CSR) of the company PT Tirta Investama AQUA Lestari. This area was chosen as the location and object of the research based on the following considerations: (1) it is a region once known as a pocket of poverty that has now developed into a region with a productive economy; (2) historically, this region has been advanced by the implementation of a CSR program; (3) this region is the target of a CSR program of a single company, without any intervention from other companies. The research was conducted from March 2018 to December 2018. Informants were 66 people from a total population of 3256 people consisting of 1,736 men and 1520 women. The informants are representatives of community leaders, farmers, women farmer groups, dasa wisma groups, small and medium business actors, local youth organizations.

This research uses a qualitative method which focuses on an investigation of the way human beings interpret values of local wisdom and the significance of participation in the development of the organic tourist village. That method is inclined to be connected to the subjective nature of a social reality [22, 23, 24, 25].This case it is the method used for producing an understanding of the perspective of stakeholders in the development of the organic tourist village, which enables the researchers to view various things as they are viewed by their practitioners. The research is a case study, which explores a phenomenon in the real life context of a community [26]. This case the participation of the community which synergizes with values of local wisdom in managing its resources.

In the research of a case study, to collect data which involve various sources of information (for examples are observation, interview, focus group discussion, audio-visual material, document, and report) and report of a theme of theme-based descriptive case. The researcher collects and then organizes and analyzes data about a particular case or cases related to the problems that are the focus of the study, and subsequently compares or relates the data with other data (when more than one case is involved) while adhering firmly to 
holistic and contextual principles. In this research, the researchers aim to understand the potential of social behavior that takes place in activities involving individuals in a community, in particular concerning the extent to which the factor of macroscopic structure and the related institutions influence individual relationships [27]. The social behavior that the researchers wish to explore in depth and to understand includes the aspects of participation and local wisdom of the community in developing the tourist village of Blederan. The primary data source of qualitative research is words and actions, which is supported by secondary data in the form of documents and other sources [28]. The techniques of data collection used in this research are in-depth interviews, participant observation, focus group discussions, and documentation. For each case, the process of analysis uses an interactive analysis model [29]. In this model of analysis, the three components of the analysis are: data reduction, data presentation, and verification [29].

\section{Result and Discussion}

The village of Blederan is situated in a hilly region with a beautiful natural panorama. The people of Blederan village regard this natural beauty as a resource that has the potential to be developed as an organic vegetable tourist village which provides benefit for its community. The community are driven to participate in cultivating organic vegetables (green cabbages, lettuce, chives, spring onions, tomatoes, eggplants, chilies, green beans etc.) because they believe organic vegetables will become more widely sought after as people develop a greater sense of awareness about the importance of leading a healthy lifestyle. A community based tourist village is a development model that supports and enables complete involvement of the local community, from the planning stage to the implementation and business management of the tourist village and all the profits gained.

Table 1. Participation strategy steps for developing the organic tourist village

\begin{tabular}{|c|c|}
\hline $\begin{array}{c}\text { Local } \\
\text { Potential }\end{array}$ & Participation strategy steps \\
\hline $\begin{array}{l}\text { Product } \\
\text { Potential }\end{array}$ & $\begin{array}{l}>\text { Establishment and development of a concept for a tourist village that is } \\
\text { "different" from ones that already exist. } \\
>\quad \text { Concept for development of tourist objects based on } \\
\text { agricultural/horticultural potential as the primary commodity of the } \\
\text { local community. } \\
>\quad \begin{array}{l}\text { Promotion and development of local traditional art and culture } \\
\text { (hadrah, yasinan) to become a unique and special icon for tourists. }\end{array} \\
>\quad \text { Establishment and management of a participative based tourist } \\
\text { village by involving all stakeholders. }\end{array}$ \\
\hline $\begin{array}{l}\text { Support of } \\
\text { Human } \\
\text { Resources }\end{array}$ & $\begin{array}{l}\text { Education and training about tourist villages, in particular for people } \\
\text { living near the tourist objects. } \\
\text { Intensive instruction for local farmers/MSMEs about cultivation of } \\
\text { organic vegetables } \\
\text { Tourism based entrepreneurship courses/training for members of the } \\
\text { community of a productive age and school dropouts, teaching them } \\
\text { how to develop home industries. }\end{array}$ \\
\hline $\begin{array}{l}\text { Motivation } \\
\text { of the } \\
\text { Community }\end{array}$ & $\begin{array}{l}\text { Formation of tourist village communities/associations in clusters that } \\
\text { are concerned with the development of the tourist village. } \\
\text { Tourist village institutions actively provide information for the } \\
\text { community about the potential map of organic vegetables. }\end{array}$ \\
\hline
\end{tabular}

Data source: Analysis of in-depth Interviews and focus group discussions, 2018 
The tourist village of Blederan is a participative based tourist village, as shown by the following indicators. First, the Blederan community has knowledge about nature, enabling it to adapt to climate change and develop its local culture to become a potential selling point as a tourist attraction, so that the involvement of the community is vital. Second, the existence of this ecotourism recognizes the rights of the local people to manage the tourist activities in their own region, in a traditional way, as the primary administrators. The local people adhere strongly to the principle of local ownership, and have formed committees or institutions to manage the various activities of the tourist village in their own area, together with the support of the government and community organizations. Third, new work opportunities have been created for the local community, thereby reducing poverty. Fourth, the community has developed tourist services to provide income through guide fees, transportation costs, sale of handicraft products etc. Fifth, the religious ecology of the local community has been cultivated so that the people are able to develop their identity and sense of pride as a community, as a result of the greater number of activities of Blederan tourist village.

In Javanese philosophy there are numerous traditional sayings or words of wisdom. The Javanese people learn these words of wisdom from their elders, who teach them various life values, such as how to treat other human beings and how to treat nature, as shown in the table below.

Table 2. Local Wisdom implemented by the community in the resource management of the organic tourist village

\begin{tabular}{|l|l|l|l|}
\hline No & $\begin{array}{l}\text { Value of Local } \\
\text { Wisdom }\end{array}$ & \multicolumn{1}{|c|}{ Meaning } & \multicolumn{1}{|c|}{ Role in Resource Management } \\
\hline 1 & $\begin{array}{l}\text { Rukun agawe } \\
\text { santosa, crah } \\
\text { agawe bubrah }\end{array}$ & $\begin{array}{l}\text { Harmony increases } \\
\text { power, divide leads to } \\
\text { damage }\end{array}$ & $\begin{array}{l}\text { The community lives in harmony in their } \\
\text { management of natural resources and the } \\
\text { environment }\end{array}$ \\
\hline 2 & $\begin{array}{l}\text { Aja nggugu } \\
\text { karepe dhewe } \\
\text { free will }\end{array}$ & $\begin{array}{l}\text { Deople control their actions so as not to } \\
\text { treat nature arbitrarily, and are able to } \\
\text { control, not be controlled by, their desires. }\end{array}$ \\
\hline 3 & $\begin{array}{l}\text { Ibu bumi, bapa } \\
\text { aksa }\end{array}$ & $\begin{array}{l}\text { Mother is the earth, father } \\
\text { is the sky }\end{array}$ & $\begin{array}{l}\text { The people love, protect, and respect the } \\
\text { earth and sky in the same way we treat our } \\
\text { parents. }\end{array}$ \\
\hline 4 & Asta brata & $\begin{array}{l}\text { Eight lessons in Javanese } \\
\text { leadership }\end{array}$ & $\begin{array}{l}\text { Lessons about humanity and leadership in } \\
\text { managing resources. }\end{array}$ \\
\hline 5 & $\begin{array}{l}\text { Babad Tanah } \\
\text { Jawa }\end{array}$ & $\begin{array}{l}\text { Concept of unity in the } \\
\text { way people live together } \\
\text { with all God's creations }\end{array}$ & $\begin{array}{l}\text { Human beings are one with nature, so they } \\
\text { will not dare to destroy the natural } \\
\text { environment. }\end{array}$ \\
\hline
\end{tabular}

Data source: Primary data from in-depth interviews and focus group discussions

In agricultural development, local wisdom is a human endeavor to manage the agricultural resources and take care of them so that they are protected from damage. The development of Blederan tourist village involves all elements of the community, including the local people, local government, and even central government. The local Blederan government has taken a number of steps to increase the awareness of the community about protecting natural resources and the environment, including: (1) calling for people to protect the natural resources and surrounding environment; (2) admonishing people who fail to follow the rules; (3) drafting a law and sanctions for violators so that the violation of rules and regulations can be anticipated.

The development of Blederan tourist village has applied principles of conservation in its utilization so that it does not exceed the carrying capacity of the environment. It is 
important in the development of tourism that the maximum carrying capacity of a destination is not overlooked, to avoid causing damage to the natural and cultural environment. In a traditional village, the environment is composed of several elements of natural landscape. It is these elements that are closest to the everyday life of the local community [30].

Through the CSR program of the company AQUA Lestari, the community has been facilitated to make optimum use of its land without damaging the natural resources and surrounding environment. Relevant information or messages are usually passed on during regular community meetings in the village. These meetings are also used to discuss any problems the village is facing and to talk about possible solutions. One of the development strategies that is oriented towards sustainability or protecting the environment from damage is the utilization of natural resources based on local wisdom. The CSR program implemented by PT AQUA Lestari has enabled the village of Blederan to become one of the villages selected for the Climate Village Program (ProKlim). ProKlim is a national program established by the Ministry of the Living Environment which encourages active participation of communities and all parties to act locally and think globally about ways to increase resistance to climate change and reduce the emission of greenhouse gases.

The Blederan village community has used its local wisdom for resource management in the tourist village to (1) control drought, flooding, and landslides; (2) increase food security; 93) control climate related diseases; (4) manage garbage and solid and liquid waste; (5) process and utilize wastewater; and (6) carry out agricultural cultivation. This is in line with [31] in that the development and management of resources must be directed towards fulfilling economic, social, and aesthetic aspects, while at the same time protecting the integrity and or preservation of the ecology, biodiversity, culture, and life systems. In this way, the tourism industry can benefit the social and environmental aspects of the local community. [32] describes this as the adoption of a concept that enables environmental preservation and brings to the surface traditional values of local wisdom. As a result, this kind of tourism leads to economic growth in the community.

The sustainability and independence of the local community in developing the Blederan tourist village is supported by a long-term system that has been established. The resources used are only those that can be restored, while looking for and using the latest energy sources so as to minimize environmental damage. This is done by limiting energy absorption and minimizing consumption, as conceived by [33, 34]. The concept of sustainability is categorized in three aspects of understanding: economic, social, and environmental sustainability $[35,36]$,

The sustainability of the community in the management of its resources is manifested in the following ways: First, economic sustainability, in which the development of Blederan tourist village has managed to produce goods and services and propel productive economic enterprises in the local area while continuously preserving sustainability. As outlined by [37], investment has a positive effect on economic growth, both in the short term and long term. According to [38], the development of productive economic enterprises can indirectly lead to an increase in income for members of the community.

Second, environmental sustainability, in which the people of Blederan village have managed to take care of their stable resources, avoid exploitation of natural resources, and protect the function of environmental absorption. This concerns the preservation of the biodiversity, the stability of air space, and other functions of the ecosystem that are not included in the category of economic resources. Human settlements and the environment are integral parts of human life. Both have an effect on the quality of life of the local community. Therefore, there are numerous efforts to improve the quality of the village environment by improving the quality of people's health [39]. 
Third, social and cultural sustainability, in which the village community has managed to cultivate and develop values of social capital, local wisdom, and local culture to support the development organic tourist village. This is in line with the research which describes how the existence of a tourist village gives the local community the opportunity to meet and get to know people from a different background, so that the community starts to believe that the tourism industry has succeeded in its development by repressing any negative social and environmental effects [40, 41, 42].

The independence of the community in managing the resources of the tourist village are reflected in the following ways: (1) the ethic of entrepreneurship, which has begun to appear in the local community along with the development of the tourist village; (2) the organization of training sessions to improve the skills of local community groups; (3) the emergence of business group associations to establish relations in partnership ventures; (4) the increase of product quality alongside the improvement of skills in the local community; (5) the development of savings and loan businesses to aid the local community with start-up capital; (6) the development of an organic vegetable district in the local area which relies on local potential. Below is an illustration of the development model for a participative and local wisdom based tourist village.

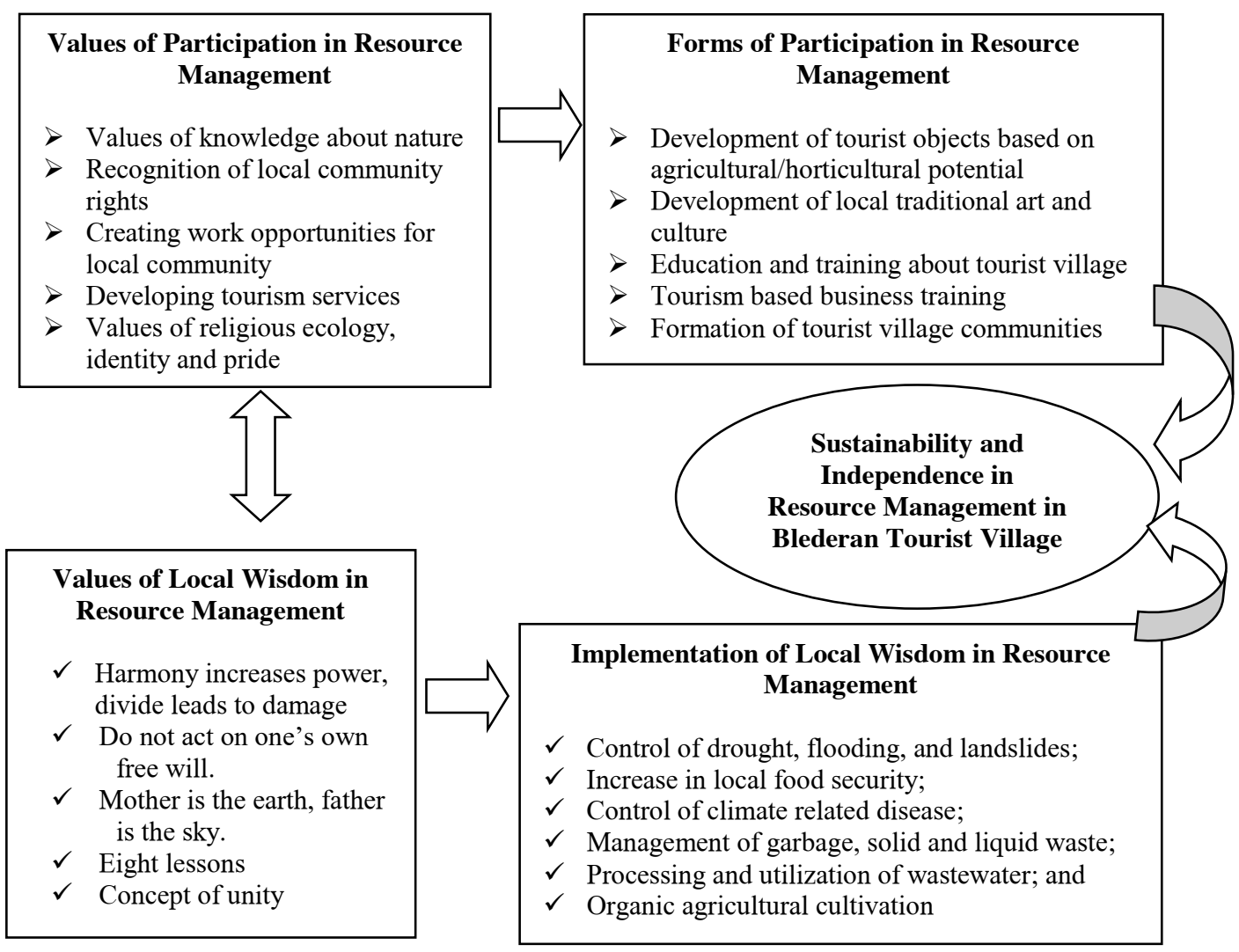

Fig. 1. Model of Resource Management Based on Participation and Local Wisdom

\section{Conclusion}

Organic tourist village of Blederan is a participative and local wisdom based tourist village. The participation in this tourist village can be seen in the development existence of local community. The role of local wisdom can be seen in: (1) the control of drought, 
flooding, and landslides; (2) the increase in food security; (3) the control of climate related diseases; (4) the management of garbage, solid and liquid waste; (5) the processing and utilization of wastewater; and (6) the agricultural cultivation. These two elements have led to the sustainability and independence of the community. The sustainability of the community in managing its resources is manifested in the following ways: First, economic sustainability, in which the organic tourist village produces goods and services and propels productive economic enterprises in the local area while continuously preserving sustainability; Second, environmental sustainability, in which the organic village community looks after its stable resources, avoids exploitation of natural resources, and protects the function of environmental absorption; Third, social and cultural sustainability, in which the village community develops values of social capital, local wisdom, and local culture to support the development of organic tourist village. Furthermore, the independence of the community in managing the resources of the tourist village is reflected in the following: (1) the ethic of entrepreneurship that has begun to appear; (2) the organization of training sessions to improve the skills of the local people; (3) the emergence of business group associations; (4) the development of better product quality along with the improvement of skills in the local community; (5) the development of savings and loan businesses in the local community; (6) the development of an organic vegetable district which relies on local potential.

\section{References}

1. Sangchumnong A. Kasetsart Journal of Social Scienes. 15: 1-8 (2018).

2. Permatasari A., Sardjono, A. B., Indriastjario, I., \& Pandelaki, E. E. Journal of Architecture and Urbanism, 43(1), 36-46. (2019).

3. Chattopadhyay P. International Educational Applied Research Journal (IEARJ) 3(1): 1-13 (2019).

4. Giacomo D, Marcello, Vahid. Journal of destination marketing \& management 23: 4554. (2018).

5. Suess C, Baloglu S, Busser JA. Journal of Tourism Management 69: 232-245 (2018).

6. Kapera I. Sustainable Cities and Society 40: 581-588. (2018)

7. Marapaung B. Procedia Social and Behavioral Sciences 234:344-352 (2017).

8. Sihombing D. International Journal of Civil Engineering and Technology (IJCIET) 10 (3): 951-966 (2019).

9. Sulaiman AI, Masrukin, Bambang S. The International Journal of Social Sciences 7 (1): 59-80 (2019).

10. Nursaid A. J Ketahanan Nasional 22 (2): 217-236 (2016)

11. Farhan, H., \& Anwar, K. Journal of Sustainable Development, 9(3), 170.

12. Gursoy D, Boğan E, Dedeoğlu BB, Çalışkan C. Journal of Hospitality and Tourism Management 39: 117- 128 (2019).

13. Bahari, Andi Faisal and Ashoer, Muhammad. Jurnal manajemen, ide, inspirasi. Vol 5(1: 69-78 (2018).

14. Kurniasih, Nihayah, D. M., Sudibyo, S. A., \& Winda, F. N. E3S Web of Conferences, 31, 1-6 (2018).

15. Herawati, Yayuk Widyastuti. Journal of LiNGUA. Vol 11 (1): 21 - 28 (2016).

16. Vincentia R. Procedia Social and Behavioral Sciences 216:97-108 (2016).

17. Andriyani, Anak Agung Istri, Edhi Martono, Muhamad. Jurnal Ketahanan Nasional. Vol. 23 No. 1 P. 1-6 (2017).

18. Shishmanova M. Procedia Social and Behavioral Sciences 188: 246-254 (2016).

19. Po Hsin, Saunders A, Grimstad. Tourism Management 58: 164-174 (2017). 
20. Chio, J. A landscape of travel: The work of tourism in rural ethnic China. Seattle: University of Washington Press (2018).

21. Zhou Y. J of Rural Tourism. 286(1): 142-144 ( 2019)

22. Daymon, Christine and Holloway, Immy. Metode Riset Kualitatif dalam Public Relations dan Marketing Communications. Yogyakarta:Penerbit Bentang 4 (2008)

23. Creswell, John W. Qualitative Inquiry and Research Design: Choosing among Five Approaches. Thousand Oaks,.CA: Sage 73 (2006)

24. Bungin, B. Metodologi penelitian kualitatif: Aktualisasi metodologis ke arah ragam varian kontemporer. 87 (2019).

25. Manzilati, A. Metodologi Penelitian Kualitatif: Paradigma, Metode, dan Aplikasi. Universitas Brawijaya Press. 5-6 (2017)

26. Rukajat, A. Pendekatan Penelitian Kualitatif (Qualitative Research Approach). Deepublish) (2018)

27. Pawito. Penelitian Komunikasi Kualitatif. Yogyakarta:LKIS 141 (2007)

28. Moleong, Lexy, J. Metodologi Penelitian Kualitatif. Bandung: PT Remaja Rosdakarya 112 (2009)

29. Miles, Matthew. B and Huberman, A. Michael. Analisis Data Kualitatif. (Translated by Tjetjep Rohendi Rohidi). Jakarta: Universitas Indonesia 16 (1992)

30. Shawei Z, dinghang W, Zhong Y. IOP Conf. Ser.: Earth Environ. Sci. 153 (2018).

31. Dewi NIK, Astawa IP, Siwantara IW, Mataram IGAB. Journal of Physics: Conf. Series 953(1): 012-072 (2017).

32. Prayudi A. Widyantoro, A., Moechthar, O., \& Airlangga. PEOPLE: International Journal of Social Sciences, 3(3), 527-542.

33. Ife, Jime. Community Development: Creating Community Alternatives-Vision, Analysis and practice. Melbourne: Longman. (1995)

34. Ife, Jim. Tesoriero, Frank. Community Development: Alternatif Pengembangan Masyarakat di Era Globalisasi. Yogyakarta: Pustaka Pelajar. (2008)

35. Fauzi. Ahmad., Ekonomi Sumber Daya Alam dan Lingkungan, Teori dan Aplikasi. Jakarta: Gramedia Pustaka Utama. (2004)

36. A. S. Hamzah és M. Irfan, in Proc. Int. Conf. Bus. Law Local Wisdom Tour. (ICBLT 2018) (Atlantis Press, Paris, France, 2018).

37. Ali N, Hamid H. Impact of foreign direct investment on the economic growth of Pakistan. J American Economics 7(4): 163-170 (2017).

38. Shauna M, Morin, Audrey $\mathrm{J}$ et al. The state of community engagement in graduate education: reflecting on 10 years of progress. J of Higher Education Outreach and Engagement 2(1): 151-156 (2016).

39. Matthew P. Impact of responsible tourism on destination sustainability and quality of life of community in tourism destinations. 31: 83-89 (2017).

40. Joanne P, Sarah P, Richard W. Social tourism and well-being in a first nation community. Annals of Tourism Research 77: 38-48 (2019).

41. Lee TH, Jan FH. Can community-based tourism contribute to sustainable development? Evidence from residents' perceptions of the sustainability. Journal of Tourism Management 70: 368-380 (2019).

42. Zhang Y, Timothy JL, Yu X. A conflict resolution model for sustainable heritage tourism. International Journal of Tourism Research 21:478-492 (2019). 